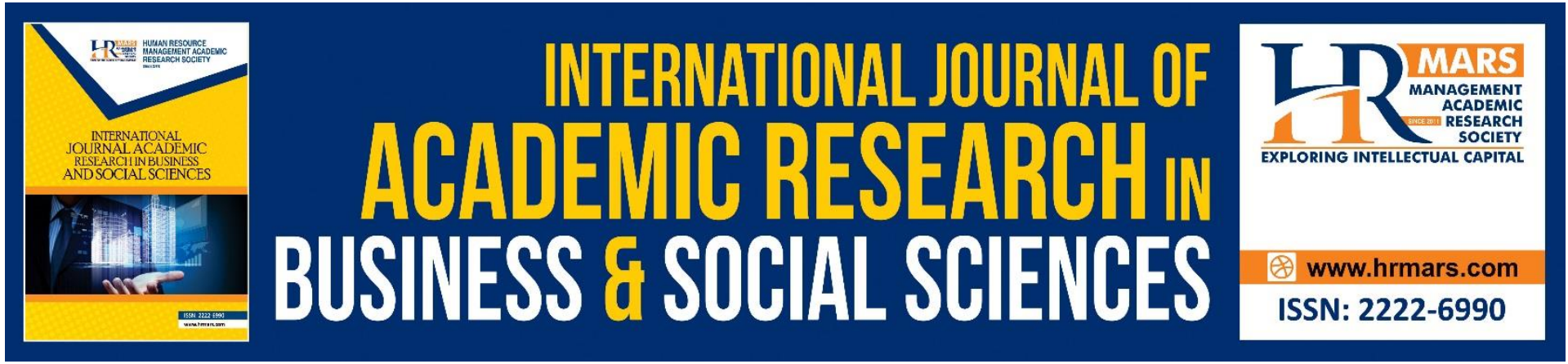

\title{
Peer Influences: Risk Factors to Voluntary and Non- Voluntary Clients to Remain Abstinence
}

Amin Al Haadi Bin Shafie, Mizan Adiliah Ahmad Ibrahim, Abdul Rashid Bin Abdul Aziz, Amer Fawwaz Bin Mohamad Yasid, Nur Amalina Binti Abd Laziz

To Link this Article: http://dx.doi.org/10.6007/IJARBSS/v11-i9/10994 DOI:10.6007/IJARBSS/v11-i9/10994

Received: 08 July 2021, Revised: 28 July 2021, Accepted: 19 August 2021

Published Online: 11 September 2021

In-Text Citation: (Shafie et al., 2021)

To Cite this Article: Shafie, A. A. H. Bin, Ibrahim, M. A. A., Aziz, A. R. B. A., Yasid, A. F. B. M., \& Laziz, N. A. B. A. (2021). Peer Influences: Risk Factors to Voluntary and Non-Voluntary Clients to Remain Abstinence. International Journal of Academic Research in Business and Social Sciences, 11(9), 270-281.

Copyright: (c) 2021 The Author(s)

Published by Human Resource Management Academic Research Society (www.hrmars.com) This article is published under the Creative Commons Attribution (CC BY 4.0) license. Anyone may reproduce, distribute, translate and create derivative works of this article (for both commercial and non-commercial purposes), subject to full attribution to the original publication and authors. The full terms of this license may be seen at: http://creativecommons.org/licences/by/4.0/legalcode

Vol. 11, No. 9, 2021, Pg. 270 - 281

Full Terms \& Conditions of access and use can be found at http://hrmars.com/index.php/pages/detail/publication-ethics 


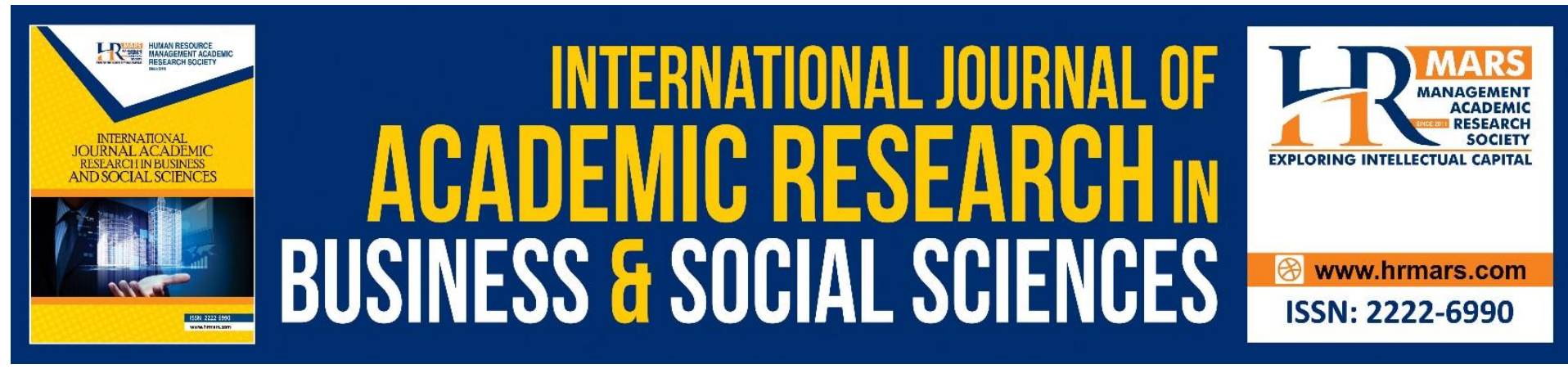

\title{
Peer Influences: Risk Factors to Voluntary and Non-Voluntary Clients to Remain Abstinence
}

\author{
Amin Al Haadi Bin Shafie1, Mizan Adiliah Ahmad Ibrahim", \\ Abdul Rashid Bin Abdul Aziz², Amer Fawwaz Bin Mohamad \\ Yasid $^{3}$, Nur Amalina Binti Abd Laziz² \\ ${ }^{1}$ Asian Centre of Research on Drug Abuse, University Sains Islam Malaysia, 71800 Nilai, \\ Negeri Sembilan, Faculty of Leadership and Management, ${ }^{2}$ University Sains Islam Malaysia, \\ 71800 Nilai, Negeri Sembilan, ${ }^{3}$ Universiti Pertahanan Nasional Malaysia, 57000 Kuala
}

Lumpur

\begin{abstract}
Drug cases among teenagers are on the rise from year to year. Their involvement is said to be due to many risk factors, and one of them is the risk factor of peer influences. Many efforts were implemented by the government and authorities to treat the issues of drug abusers, including providing treatment and rehabilitation services. However, the tendency to remain abstinent may be different based on the risk factors, types of clients, and conditions of the clients. Therefore, this paper is undertaken to identify the comparison in peer influence risk factors between four groups which are voluntary clients, non-voluntary clients, clients who underwent the treatment at the center, and clients after undergoing the treatment at the center in the tendency to remain abstinence. Besides, this paper is undertaken to explore the risk factor of peer influences to relapse in drug problems. A comparison study with a mixedmethod design involving qualitative and quantitative methods has been adopted in this study. The study participants were recruited based on purposive sampling technique and 24 private treatment centers were involved in this study. A mixed triangulation method was implemented for data collection of quantitative and qualitative data. Quantitative data were collected using structured questionnaires and the Stage of Change Scale (SoCS) while qualitative data were collected through interviews and using semi-structured questionnaires. Quantitative data were analyzed using descriptive statistics to summarize and describe the study's findings. T-test was conducted to identify the differences of viewpoints between voluntary and non-voluntary clients and meanwhile, the qualitative data were analyzed by theme. Four hypotheses were tested and hypothesis 1 was accepted. The finding from the hypothesis 1 revealed that there are significant differences for peer influences risk factors based on non-voluntary and voluntary clients who are still undergoing treatment at the center. Non-voluntary clients, who are still undergoing treatment are reported more affected by the risk of peer influences to remain abstinent than voluntary clients. Meanwhile, the findings from the interview revealed that peer influence factors became a motivator for relapse in drug issues among voluntary clients, non-voluntary clients, clients who are still undergoing treatment at the center, and clients after undergoing the treatment at the center.
\end{abstract}


Hence, it showed that peer influence was a significant risk factor for voluntary and nonvoluntary clients to remain abstinent and relapse in drug issues. The further researchers proposed the study on the develops support module for parents in managing children who are involved in drug abuse so that they can remain abstinent.

Keywords: Peer Influence, Risk factor, Voluntary Client, Non-voluntary Client, Abstinence, Drug Abuse

\section{Introduction}

Day after day, the drug problems had begun to be perceived as a threat to national security instead of contributes to increases in social problems among the youth. Additionally, in conjunction with the National Anti-Drug Day celebration, Tun Dr. Mahathir bin Mohamad, the fourth Prime Minister of Malaysia had been declared drugs as the number one enemy of the country on 19 February 1983. The National Drug Policy was introduced in 2004 for recognizing the danger of drugs and to create a drug-free Malaysia by 2015 to ensure the well-being of the community, as well as to maintain the nation's stability and resilience ( Shafie et al., 2015).

The drug cases showed decreased in 2018, however, the pattern of age groups beginning to be involved with drug abuse is worrying, namely as early as 10 years old compared to 20 years old in the 80s (Tan et al., 2007). In addition, Isa et al (2018) revealed that the number of adolescents involved with drug abuse is increasing every year. These adolescents tend to abuse substances when they feel that there is no other way to solve their problems. Moreover, peer influence is the second most important influence on adolescents' life after their family of origin (Ogel, 2001). Typically, friend relationships give a significant influence on the adolescent to face their reality, to know themselves better as well as of their emotions and thoughts (Yildirim, 2008).

However, friend relationships became risky when there are substance abusers in the circle of an individual, and adolescents with an addicted abuser may have the tendency to engage in substances abuse as well (Ogel et al., 2005). Adolescents with substance abuse issue may get the supports if they have a groups of friends who have a positive attitude towards substance abuse. Similarly, an adolescent who abuses the substances may develop addiction problem as they gained the influence and support from their friends who is a drug addict (Kasatura, 1995). The desire of an adolescent to be included in a peer group and them being isolated from their friend circle may be pulled into substance abuse.

Therefore, many efforts and approaches gave by The National Anti-Drug Agency (AADK), for instance in providing treatment services to drug users, addicts and, drug abusers that voluntary and non-voluntary. Voluntary clients will go through section 8 (3) (a) of the Drug Addicts (Treatment \& Rehabilitation) Act 1983. They will undergo treatment within 6 months to 24 months. For non-voluntary clients, they are those who have been ordered through the provisions of section 6 (1) (a) of the Drug Addicts (Treatment \& Rehabilitation) Act 1983 to undergo treatment and rehabilitation for a period not exceeding 24 months. These former drug addicts will return to their families and community after they undergo treatment at the AADK treatment center. In the meantime, it showed that $28.86 \%$ of the drug cases detected in 2017 were from the group of relapse addicts. From 2017 to 2018, a total of 25, 922 relapse addicts were detected nationwide (Kamarudin \& Bahaudin, 2018). Hence, in this study, the researcher examines the risk factors of peer influences between voluntary, non-voluntary clients, clients who undergoing the treatment at the center and clients after undergoing the treatment in the tendency to remains abstinent from drug abuse. 


\section{Literature Review Risk Factor}

NIDA Notes explains that in general, the greater the risk factors present in a client, the higher the propensity for the client to engage in drug abuse. These risk factors are associated with the aspect of environment and biology. From the biological perspectives, it is related to the factors of genetic, developmental growth stage, gender, and also ethnic. The environmental factor refers to family issues, schooling with the influence of peers, and also the neighbourhood (National Institute Drug Abuse, 2020). Furthermore, it is being highlighted that parents or older family members who are indirectly involved in drug abuse may increase the risk of the child's predisposition to drug abuse in the future (Biederman et al., 2000).

Moreover, early exposure and involvement in the drug abuse issue, may increases the tendency for an individual to get severe in drug addiction (Substance Abuse and Mental Health Services Administration, 2020). According to Squenlia et al (2009) among another factor that being highlights is the method of drug abuse. The way of taking or injecting the drugs into the bloodstream will further increase the risk of drug addiction. A study conducted by Atherton et al (2016) examined the risk and protective factors for early substance use initiation among youth. The findings demonstrated that risk factors towards the tendency to drug abuse are those who have high and strong desire to try drugs, have easy access to obtain drugs, lack of self-control, individual who have less moral peer influence, individual who living alone at home without adult supervision, lack of parental monitoring as well as having siblings involved with immoral behavior.

\section{Abstinence}

The American Society of Addiction Medicine (2013) defines abstinence as a deliberate desire and a consistent feeling of self-restraint to engage in the negative things to obtain rewards as well as satisfaction in the form of substance abuse or behavior. According to Abedi et al (2016) the tendency to remain abstinent from drug abuse depends on several important elements which are; cohesive community support, a sense of equality, values of responsibility and love, feelings of sympathy, having a similar life journey and observation of other individuals who have successfully remain abstinent from drug abuse. In addition, other important elements to remain abstinent include encouragement in the group towards new members to remain abstinent, activities, and contributions within the group to stay abstinent together as well as practicing religious and spiritual values to motivate themselves towards positive abstinence.

A study conducted by Mohammad et al (2017) investigated the percentage rate of abstinence after undergoing the aftercare treatment of drug abuse among clients. The findings showed that from a total of 19 clients who received treatment for more than 30 days, 16 clients (84.2\%) had a successful 12-month treatment outcome rate. This is in contrast to among 53 clients who received a 30-day treatment program, the study found that a total of 29 clients (54.7\%) had a successful 12-month treatment outcome rate. Thus, in a study involving drug abuse treatment and rehabilitation programs, treatment of more than 30 days was significantly associated with better treatment outcomes.

Meanwhile, another study by Nen et al (2017) examined the level of self-confidence among former drug addicts under supervision, known as Supervised Persons (OKP). These former drug addicts were undergoing rehabilitation within a period of 6-11 months (group 1), 
and who were discharged between 12-24 months (group 2). The findings showed that the majority of these groups did not show a significant difference in recovery in terms of selfconfidence. Therefore, the level of self-confident among the majority of both groups showed a moderate level which is $58.5 \%$. However, group 1 showed a higher percentage of selfconfidence (63.5\%) compared to group 2 (53.8\%).

\section{Voluntary Client}

Voluntary clients through section 8 (3) (a) of the Drug Addicts (Treatment \& Rehabilitation) Act 1983 will undergo drug addiction and rehabilitation treatment. The treatment period is a minimum of 6 months and a maximum of 24 months which is two years. Furthermore, these voluntary clients are not bound by the legal implications. Hence, testing and evaluation for drug abuse will be conducted on voluntary clients before admission and no law applies to such clients. In addition, the voluntary client was offered a few services such as inpatient or outpatient treatment which includes detoxification using medication, counseling and guidance, religion and spirituality, relapse prevention education, life skill, fiber therapy treatment using methadone, support groups assistance, referral and advocacy. These treatments provided are including towards the client's family, spouse, friends, employers, or significant individuals related to the client.

\section{Non-voluntary Client}

Non-voluntary clients, are those who have been ordered through the provisions of section 6 (1) (a) of the Drug Addicts (Treatment \& Rehabilitation) Act 1983 to undergo treatment and rehabilitation for a period not exceed than 24 months. Among the transformational elements applied to the non-voluntary client are the biopsychosocial and spiritual program approach as well as a change in the client's image and conducive environment. There are 10 components of the treatment and rehabilitation program that must be followed by all nonvoluntary clients. For examples are early rehabilitation, re-addiction prevention, social support, religion, and spiritual program, guidance and counseling, skills vocational training, sports, and leisure, health care, parades and physical as well as family programs.

\section{The Differences between Voluntary and Non-Voluntary Client to Remain Abstinent}

A descriptive study conducted by Shafie et al (2015) which identified the effects of treatment towards the level of mental and spiritual health, quality of life, period to remain abstinent, and stage of changes among respondents who undergo the treatment, medical and rehabilitation Clinics in peninsular Malaysia. The findings regarding the period of remain abstinent among respondents revealed that $46.2 \%$ of respondents failed to remain abstinent less than the first 6 months after the treatment. Compared to $38.7 \%$ of respondents who managed to remain abstinence for more than 6 months. While $28.1 \%$ of respondents refused to state the status at any time. The researcher assumed that it is likely that the respondent never recovered or relapsed in less than a month after completing the treatment at the $C$ \& C1M Clinic. The researcher also stated that most respondents did not consistently attend follow-up programs with addiction counselors.

Moreover, Coviello et al (2013) investigated the level of completion rates among nonvoluntary clients who were under court order to undergo drug abuse and treatment and rehabilitation with voluntary clients. The study found that even though non-voluntary clients initially showed a lack of motivation at the beginning of treatment, they were more likely to 
complete the treatment compared to voluntary clients. Hence, it showed that non-voluntary clients were ten times more likely to complete treatment provided compared to voluntary clients.

\section{Methodology}

\section{Research Design}

This study has conducted a comparative study to see the differences and similarities of the tendency to remain abstinent between voluntary and non-voluntary clients. A mixed-method design (qualitative and quantitative data) has been adopted in this study. Creswell (2008) asserted that quantitative and qualitative data will be collected in a mixed-method study. It involves data in the form of numbers, words, and images. Besides, mixed-method is used when to facilitate understanding of the study problem statement. Table 1.0 below is the framework of the study that explains on how the researcher conducted the study.

Table 1.0: Framework of the Study

\begin{tabular}{|l|l|l|l|l|}
\hline $\begin{array}{l}\text { Types of } \\
\text { Admission }\end{array}$ & $\begin{array}{l}\text { Treatment } \\
\text { Process }\end{array}$ & $\begin{array}{l}\text { First Data } \\
\text { Collection }\end{array}$ & $\begin{array}{l}\text { Client } \\
\text { Exempted }\end{array}$ & $\begin{array}{l}\text { Second Data } \\
\text { Collection }\end{array}$ \\
\hline $\begin{array}{l}\text { Voluntary } \\
\text { Admission }\end{array}$ & $----------->$ & $\begin{array}{l}\text { End of } \\
\text { Treatment } \\
\text { Period }\end{array}$ & $----------->$ & $\begin{array}{l}\text { After 6 Month of } \\
\text { Exemption }\end{array}$ \\
\hline $\begin{array}{l}\text { Involuntary } \\
\text { Admission }\end{array}$ & $----------->$ & $\begin{array}{l}\text { End of } \\
\text { Treatment } \\
\text { Period }\end{array}$ & -----------> & $\begin{array}{l}\text { After 6 Month of } \\
\text { Exemption }\end{array}$ \\
\hline
\end{tabular}

\section{Sample}

The study participants were recruited based on the purposive sampling method. It is the deliberate choice of a participant due to the qualities the participant possesses (Tongko, 2007). Hence, treatment centers that accept voluntary clients and those that accept clients by court order (non-voluntary clients) were used as a guide in sample selection. A total of 24 treatment centers were involved in this study. Seven centers accept voluntary client, and 17 centers accept clients under court orders (non-voluntary clients). From the 24 identified treatment centers, 740 participants were chosen randomly. Two groups of data have been collected from selected respondents, namely quantitative data and qualitative data. Table 2.0 below is the breakdown of the group of study respondents following the breakdown of treatment centers.

Table 2.0: Total Breakdown of Respondents According to Voluntary and Non-Voluntary Classification

\begin{tabular}{|l|l|l|l|l|}
\hline & \multicolumn{2}{|l|}{ Voluntary } & Non-voluntary \\
\cline { 2 - 5 } & $\begin{array}{l}\text { Quantitative } \\
\text { Data }\end{array}$ & $\begin{array}{l}\text { Qualitative } \\
\text { Data }\end{array}$ & $\begin{array}{l}\text { Quantitative } \\
\text { Data }\end{array}$ & $\begin{array}{l}\text { Qualitative } \\
\text { Data }\end{array}$ \\
\hline Under Treatment & 90 & 22 & 298 & 64 \\
\hline After -Treatment & 36 & 9 & 175 & 46 \\
\hline Overall Total & 126 & 31 & 473 & 110 \\
\cline { 2 - 5 } & 157 & 583 & \\
\hline
\end{tabular}




\section{Data Collection}

A mixed triangulation method was applied for the data collection process of qualitative and quantitative data. This triangulation approach involves the use of more than one research method or more than one data collection technique (Perone \& Tucker, 2003). In the quantitative study, the data were collected from the structured questionnaires and stage of change scale (SoCS) measuring tool. The semi-structured interview questionnaire was conducted twice to voluntarily and non-voluntary clients to collect the qualitative data. Overall, the data collected to answer the research questions of the study were gained from the interviews, test tools, observations, and journals.

\section{Data Analysis}

The quantitative and qualitative analysis data were involved in this study. The quantitative data collected is analyzed based on the structured questionnaires and stage of change scale (SoCS) those collected. Descriptive analysis was conducted to describe the socio-demographic characteristics of the study population. Besides, the inferential analysis of the t-test was done to compare whether the means of the two groups are statistically different from each other. Meanwhile, the qualitative data collected from the interview questions of this study were analyzed according to the themes or content analysis and research questions. Data in the form of percentages were collected to support the quantitative data that had been collected.

\section{Results}

\section{Quantitative Results}

For the result of quantitative data, a t-test was measured four hypotheses of the differences in peer influence risk factors between voluntary and non-voluntary clients who were in treatment and after the treatment.

1) Ho1: There was no significant difference for peer influence risk factors between nonvoluntary and voluntary clients who were still undergoing treatment at the center.

Table 3.0: Comparison of t-test Values between Non-Voluntary Clients and Voluntary Clients in Treatment for Peer Influence Risk Factors

\begin{tabular}{lccl}
\hline \multicolumn{1}{l}{ Pair 1 } & Mean & T & $\begin{array}{l}\text { Sig. } \\
\text { (2-tailed) }\end{array}$ \\
\hline $\begin{array}{l}\text { Non-Voluntary } \\
\text { (In Treatment) } \\
\begin{array}{l}\text { Voluntary } \\
\text { Treatment) }\end{array}\end{array}$ & (In 19.422 & 2.214 & 0.029 \\
\hline to the table 3.0, the t-value stated was 2.214 (p=0.029<0.05). Hence, the null
\end{tabular}

According to the table 3.0, the t-value stated was $2.214(p=0.029<0.05)$. Hence, the null hypothesis is rejected and hypothesis 1 is supported. This means that there are significant differences for peer influences risk factors between non-voluntary and voluntary clients who are still undergoing treatment at the center.

2) Ho2: There were no significant differences for peer influence risk factors between non-voluntary and voluntary clients after undergoing treatment at the center. 
Table 4.0: Comparison of T-test Values between Non-Voluntary Clients and Voluntary Clients after Treatment for Peer Influence Risk Factors

$\begin{array}{llll}\text { Pair } 1 & \text { Mean } & \text { T }\end{array}$

(2-tailed)

\begin{tabular}{|c|c|c|c|}
\hline $\begin{array}{l}\text { Non-voluntary } \\
\text { (After Treatment ) }\end{array}$ & 20.937 & 1.790 & 0.080 \\
\hline $\begin{array}{l}\text { Voluntary } \\
\text { (After Treatment) }\end{array}$ & 18.971 & & \\
\hline
\end{tabular}

According to the Table 4.0, the t-value stated was 1.790 ( $p=0.080>0.05)$. Thus, the null hypothesis is accepted. This means that there are no significant differences for peer influences risk factors between non-voluntary and voluntary clients after the treatment.

3) Ho3: There were no significant differences in peer influence risk factors between non-voluntary clients who were still undergoing treatment in the center and nonvoluntary after undergoing treatment at the center.

Table 5.0: Comparison of t-test Values between Non-Voluntary Clients in Treatment and Non-Voluntary Clients After Treatment for Peer Influence Risk Factors

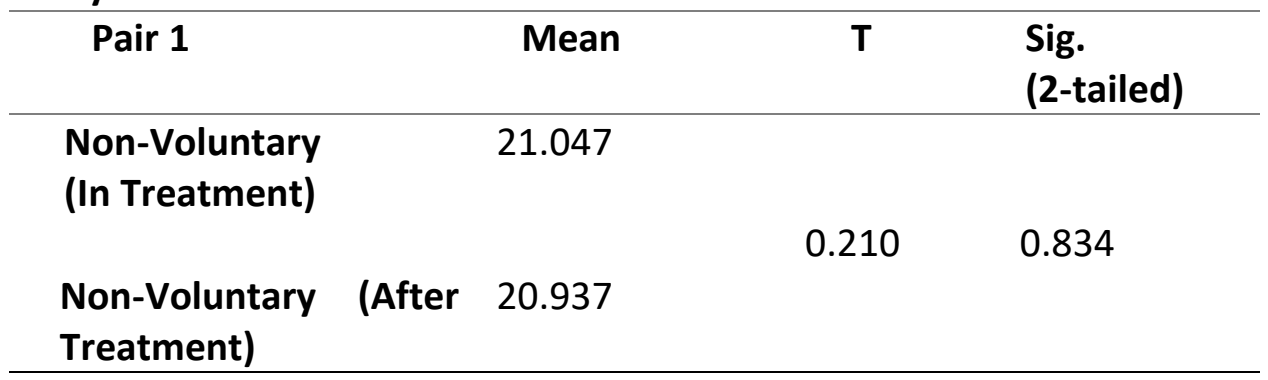

According to table 5.0, the t-value stated was $0.210(p=0.834>0.05)$. Thus, the null hypothesis is accepted. This means that there is no significant difference in peer influence risk factors between non-voluntary clients who are still undergoing treatment in the center and nonvoluntary after undergoing the treatment at the center.

4) Ho4: There were no significant differences for peer influence risk factors between voluntary clients who undergoing treatment in the center and non-voluntary after undergoing treatment at the center.

Table 6.0: Comparison of t- test Values between Voluntary Clients in Treatment and Voluntary Clients After Treatment for Peer Influence Risk Factors.

\begin{tabular}{lccl}
\hline Pair 1 & Mean & t & $\begin{array}{l}\text { Sig. } \\
\text { (2-tailed) }\end{array}$ \\
\hline $\begin{array}{l}\text { Voluntary } \\
\text { (In Treatment) }\end{array}$ & 19.449 & & \\
$\begin{array}{l}\text { Voluntary(After } \\
\text { Treatment) }\end{array}$ & 18.971 & 0.395 & 0.694 \\
\hline
\end{tabular}


According to table 6.0 , the t-value stated was $0.395(p=0.694>0.05)$. Hence, the null hypothesis is accepted. This means that there are no significant differences for peer influences risk factors between voluntary clients who are still undergoing treatment and voluntary clients after undergoing treatment at the center.

\section{Qualitative Results}

For the qualitative data, interview sessions were conducted to identify the influences of peer factor as a motivator to relapse in drug issue among voluntary client at the center, nonvoluntary client at the center, voluntary client after undergoing treatment, non-voluntary client after undergoing treatment.

\section{Voluntary Client at the Center}

Qualitative data collected through interviews with voluntary clients at the center revealed that peer influence factors became the motivators for their return to drugs. Entails below are the feedbacks that have been given:

"There is a little bit of that. For example, my friends asking me to take that 'thing' back. But, nowadays since I am working, So I think I don't have time to follow them" (PM/01/S03)

"Because of the external and internal factors triggered, close friends too, and whoever who give for it. It is giving the test to my patience level. (SHS/01/SO2)

\section{Non-voluntary Client at the Center}

Data collected from the interviews with the non-voluntary clients at the center, the peer influence factors were mentioned as a motivator for their return to drugs issue. Entails below are the feedback that has been given:

"The biggest challenge is when we meet our old friends who we know are drug addicts as well. Many of us have already changed but there is a numbers of them, still involved with drugs. If we find someone who is too addicted to the drug, it is difficult for us. Therefore, it needs to be avoided" (TB/01/BS01)

"If you want to know, these drug addicts can identify other drug addicts, even if they are not told. Just by talking to them, we can feel they are drug addicts as well. If we can avoid it, we will avoid it. However, usually, if we talking with them, we feel challenged if they said they want to take drugs" (TB/01/BSO2)

\section{Voluntary Ex-Client After Undergoing Treatment}

Data collected from the interviews with the voluntary clients after undergoing the treatment, the peer influence factors were revealed as a motivator for their return to drugs issue. Entails below are the feedback that has been given:

"As for me, it comes from friends. When I met a new friend, we got acquainted, became friends, and later he would try to persuade me to take this drug" (MT/02/BSO2)

"If I come back here, the news must reach to them. I told my mom that I'm not taking the drugs anymore, I'm just going out. However, if once I am going out, I cannot hold myself from taking back the drugs." (PK/02/BS2).

\section{Non-voluntary Ex-Client After Undergoing Treatment}

Data collected through interviews with non-voluntary clients after undergoing the treatment revealed that peer influence factors became the motivators for their return to drugs issue. Entails below are the feedbacks that have been given: 
"The biggest challenge is when we meet with an old friend who we know them, the drug addicts as well" (TB/02/BS01)

"If the friends are the same as me, I do not support them. We have to prevent ourselves from accepting their offer to take drugs" (SS/02/BS01).

\section{Discussion}

Based on the quantitative data results, peer influences risk factors showed significant differences based on non-voluntary and voluntary clients who are still undergoing treatment. Non-voluntary clients, who are still undergoing treatment are reported more affected by the risk of peer influences to remain abstinent than voluntary clients. Meanwhile, the findings from the interview sessions revealed peer influences risk became one of the motivators to relapse in drug problems among voluntary clients at the center, involuntary clients at the center, voluntary clients after undergoing the treatment, and non-voluntary clients after undergoing the treatment at the center. It showed that close friends play a huge role in influences an individual to relapse and consume back with the drugs. This is because, former drug addicts want to be accepted in their peer groups, seeking empathy and feeling of belonging from their peer group (Ranisesiki \& Sigelman, 1992; Cheung et al., 2003; Hammerbacher \& Lyvers, 2006).

Furthermore, Ariffin et al. (2019) stated that friends are the mezzo system closest to drug users after the family. Therefore, support from friends is likely to be able to give them strength to stay abstinent or return to drugs. Peers give the same significant effect as a family towards respondents. Peers can be motivators and can also be a deterrent that prevents respondents from involving directly in the world of addiction. Friend selection, friend selection skills, and the ability to control oneself from negative peer influences are important for individuals. Even though the need to have a friend is undeniably important for every individual, but the ability in choosing a friend and be a good friend is a skill needed by individuals since early adolescence.

\section{Conclusion}

After analysis of data, it can be concluded that there are significant differences for peer influences risk factors between non-voluntary and voluntary clients who are still undergoing treatment at the center. Hence, it showed that peer factors risk factors became the significant barrier for non-voluntary clients to get the treatment successfully. Meanwhile, data from the interview revealed that peer influence factors become among the motivators for their return and relapse to drugs. Peer influences became the motivator for their return to drug issues in all these four groups of the study criteria which is towards voluntary clients, non-voluntary clients, clients who are still undergoing the treatment at the center, and lastly, clients after undergoing the treatment at the center.

\section{References}

Abedi, H., Rizi, M. N., Nasrollah, A. M., Ghodoosi, A., Navidian, A. (2017). Addiction abstinence as an accessible experience: A phenomenological study. International Journal of High Risk Behaviors and Addiction. 6(1), 1-7. https://doi.org/10.5812/ijhrba.31241.

American Society of Addiction Medicine. (2013). Terminology related to addiction, treatment, and recovery.http://www.williamwhitepapers.com/pr/dlm_uploads/ASAM-RecoveryTerminology-2013.pdf. 
Ariffin, N. M., Nasir, N. C. M., Kamaluddin, M. R. (2019). Faktor-faktor penagihan semula dalam kalangan belia. Malaysian Journal of Youth Studies, 69-77.

Atherton, O. E., Conger, R. D., Ferrer, E., \& Robins, R. W. (2016). Risk and protective factors for early substance use initiation: A longitudinal study of mexican-origin youth. Journal of research on adolescence, 26(4), 864-879. https://doi.org/10.1111/jora.12235.

Biederman, J., Faraone, S. V., Monuteaux, M. C., \& Feighner, J. A. (2000). Patterns of alcohol and drug use in adolescents can be predicted by parental substance use disorders. Pediatrics, 106(4), 792-

797. https://doi.org/10.1542/peds.106.4.792.

Cheung, C.-K., Lee, T.-Y., \& Lee, C.-M. (2003). Factors in successful relapse prevention among Hong Kong drug addicts. Journal of Offender Rehabilitation, 37(3-4),179-199. https://doi.org/10.1300/J076v37n0310.

Coviello, D. M., Zanis, D. A., Wesnoski, S. A., Palman, N., Gur, A., Lynch, K. G., \& McKay, J. R. (2013). Does mandating offenders to treatment improve completion rates? Journal of substance abuse treatment, 44(4), 417-425. https://doi.org/10.1016/j.jsat.2012.10.003.

Creswell, J. W. (2008). Research design: Quantitative, qualitative, and mixed methods approaches. Sage Publications.

Hammerbacher, M., \& Lyvers, M. (2006). Factors associated with relapse among clients in Australian substance disorder treatment facilities. Journal of Substance Use, 11(6), 387394.

https://doi.org/10.1080/14659890600708266.

Isa, F. M., Ismail, R., Hassan, N. (2018). The role of social support towards depression among adolescent drug addicts. Jurnal Psikologi Malaysia, 32(3), 109-118.

Kamarudin, F., \& Bahaudin, N.H. (2018, Oktober 17). 25, 922 penagih berulang tahun lalu. BH Online. https://www.bharian.com.my/berita/kes/2018/10/487230/25922-penagihberulang-tahun-lalu.

Kasatura, I. (1995). Alkol ve Arkadaslara kitabi. Istanbul: Sistem Yayincilik.

Mohammad, A., Irizarry, K. J., Shub, R. N., \& Sarkar, A. (2017). Addiction treatment aftercare outcome study. Open Journal of Psychiatry, 7, 51-60.

https://doi.org/10.4236/ojpsych.2017.71005.

National Institute Drug Abuse. (2020). Chapter 2: risk and protective factors. U.S. Department of Health and Human Services, National Institutes of Health.

https://www.drugabuse.gov/publications/principles-substance-abuse-prevention-earlychildhood/chapter-2-risk-protective-factors.

Nen, S., Ibrahim, F., Zakaria, E., Sani, M. N., \& Saim, N. J. (2017). Tahap keyakinan diri bekas penagih dadah dalam pengawasan di Malaysia: ke arah kepulihan menyeluruh (selfesteem among former drug addicts under observation in Malaysia: towards a comprehensive recovery). Jurnal Psikologi Malaysia, 31 (1), 29 - 39.

Ogel, K. (2001). Innsan, yaşam ve bagımlılık tartışmalar ve gerekçeler. İstanbul: IQ Kültür Sanat Yayıncilı, 1-20.

Ogel, K., Taner, P. D. S., Tosun, M. D., Gurol, D. T., \& Liman, P. O. (2005). Substance use patterns of hospitalized adolescent inhalant users: A comparison according to gender and place of residence, Journal of Dependence, $6,76-83$. 
Perone, J. S., \& Tucker, L. (2003). An exploration of triangulation of methodologies quantitative and qualitative methodology fusion in an investigation of perceptions transit safety. (Report No. NCTR-416-08.1.2.) National Center for Transportation Research.

http://www.dot.statw.fl.us/researchcenter/Completed _Proj/Summary_PTO/FDOT_BC137_22_rpt.pdf.

Raniseski, J. M., \& Sigelman, C. K. (1992). Conformity, peer pressure, and adolescent receptivity to treatment for substance abuse: a research note. Journal of drug education, 22(3), 185-194. https://doi.org/10.2190/rlxr-8uxc-x7wn-dvl.

Shafie, A. A. H., Husin, M. A. H., Jailani, M. R., Amat, M. I., Noor, M. K., Ahmad, Z. A., \& Jusoh, M. R. (2015). Pengesanan bekas peserta program rawatan, perubatan dan pemulihan di Klinik Cure and Care 1Malaysia. Jurnal Antidadah Malaysia, 12(1), 88-109.

Squeglia, L. M., Jacobus, J., \& Tapert, S. F. (2009). The influence of substance uses on adolescent brain development. Clinical EEG and neuroscience, 40(1), 31-38. https://doi.org/10.1177/155005940904000110.

Substance Abuse and Mental Health Service Administration. (2020). Mental and substance use disorder. https://www.samhsa.gov/disorders.

Tan, S. Y., Zainul, S. Z., \& Yam, S. L. H. (2007). dimensi psikologikal dan gaya menghadapi masalah di kalangan penghuni-penghuni pusat pemulihan dadah. Jurnal Antidadah Malaysia, 81-96.

Tongco, M. D. C. (2007). Purposive sampling as a tool for informant selection. Ethnobotany Research and Applications, 5, 147-158. https://doi.org/10.17348/era.5.0.147-158.

Yıldırım, E. (2008). Uyuşturucu kullanımının sosyolojik boyutu uyuşturucuya yönelik talep azaltımı (The sociological dimension and demand reduction of drug abuse) Unpublished Master's thesis. Kırıkkale University Institute of Social Sciences. 